\title{
EFEKTIVITAS KEGIATAN HUMAS PEMERINTAH KOTA BOGOR DAN CITRA HUMAS DIMATA PUBLIK EKSTERNAL
}

\section{EFECTIVITY OF PUBLIC RELATION'S GOVERMENT OF BOGOR CITY AND PR'S IMAGE IN EXTERNAL PUBLIC}

\author{
F Adriani, IA Ratnamulyani, Agustini \\ ${ }^{1}$ Dosen Pembimbing I Program Studi Komunikasi, Fakultas Ilmu Sosial dan Ilmu Politik, Universitas \\ Djuanda Bogor, Jl Tol Ciawi No.1 Kotak Pos 35 Bogor 16720, 2Alumni Ps. Ilmu Komunikasi, Fakultas Ilmu \\ Sosial dan Ilmu Politik, Universitas Djuanda Bogor \\ a Korespondensi: Agustini, Email: warkam_tini@yahoo.co.id
}

(Diterima: 07-12-2014; Ditelaah: 10-01-2015; Disetujui: 16-02-2015)

\begin{abstract}
Effectiveness is a measurement in terms of achievement of goals or objectives that have been determined. Effectiveness of PR activities can be seen from the activities and programs that have been prograam PR on the run. Successful Public Relations Program involves three factors: policy, implementation of these policies, and the sensitive interpretation of the events that are based on twoway communication. PR activities are public relations efforts to obtain a good image in the eyes of the external community. The image is the main target of public relations, any activity undertaken by the Public Relations to get a good response from the community. Therefore, the existence of an effective public relations in government is necessary because the PR government is spearheading the continued running of the government in dealing with people's aspirations. The purpose of this study was to determine how effective the government's public relations activities of the city of Bogor, knowing how the government's public relations image in the eyes of the public external Bogor City, and determine the relationship between the effectiveness of PR activities with the public relations image. In this study, the methods used have been Correlational methods. Correlational method is actually a continuation of the descriptive method. With descriptive methods, we collected data, arranged in a systematic, factual, and accurate (Isaac and Michael, 1981). The study was conducted from 11 April 2012 until June 11, 2012 by using data collection techniques of observation, interviews, questionnaires, and documentation. WMS data analysis using the formula (weigh the mean score) according to Siregar Bakrei to know the answers of respondents. Mentukan criteria for assessment using Likert scale. Meanwhile, to make contact using the formula Sperman Rank The results showed: first, the activities carried out by the PR so far has been effective, particularly the documentation of activities. Second, PR succeeded in forming a positive public image of an external, third, the effectiveness of a good PR successfully cultivate a good image in the eyes of the external public.
\end{abstract}

Key words: effectiveness, image, correlational

\begin{abstract}
ABSTRAK
Efektivitas merupakan pengukuran dalam arti tercapainya sasaran atau tujuan yang telah ditentukan. Efektivitas kegiatan Humas dapat dilihat dari kegiatan dan program-prograam Humas yang telah di jalankan. Program Humas yang berhasil melibatkan tiga faktor: kebijaksanaan, pelaksanaan kebijaksanaan tersebut, dan intrepretasi secara peka mengenai peristiwa-peristiwa yang berdasarkan pada komunikasi dua arah. Kegiatan-kegiatan Humas merupakan upaya-upaya Humas untuk mendapatkan citra yang baik dimata masyarakat eksternal. Citra merupakan sasaran utama Humas, setiap kegiatan yang dilakukan oleh Humas untuk mendapatkan respon yang baik dari masyarakat. Oleh karena itu, keberadaan Humas yang efektif di pemerintahan sangat diperlukan karena Humas pemerintahan merupakan ujung tombak dalam kelangsungan jalannya pemerintahan dalam
\end{abstract}


menghadapi aspirasi masyarakat. Tujuan dari penelitian ini adalah untuk mengetahui seberapa efektif kegiatan Humas pemerintah Kota Bogor, mengetahui bagaimana citra Humas pemerintah Kota Bogor dimata publik eksternal, dan mengetahui hubungan antara efektivitas kegiatan Humas dengan citra Humas. Dalam penelitian ini, metode yang digunakan adalah metode Korelasional. Metode korelasional sebenarnya kelanjutan dari metode deskriptif. Dengan metode deskriptif, kita menghimpun data, menyusunnya secara sistematis, faktual dan cermat (Isaac dan Michael,1981). Penelitian ini dilaksanakan dari 11 April 2012 hingga 11 Juni 2012 dengan menggunakan teknik pengumpulan data observasi, wawancara, kuisioner, dan dokumentasi. Analisa data menggunakan rumus WMS (weigh mean score) menurut Bakrei Siregar untuk mengetahui jawaban dari responden. Untuk mentukan kriteria penilaian menggunakan skala Likert. Sedangkan untuk mencari hubungan menggunakan rumus Sperman Rank. Hasil penelitian menunjukan : pertama, kegiatan-kegiatan yang dilakukan oleh Humas selama ini sudah efektif, khususnya kegiatan dokumentasi. Kedua, Humas berhasil membentuk citra yang positif kepada publik eksternal, ketiga, efektivitas Humas yang baik berhasil menumbuhkan citra yang baik dimata publik eksternal.

Kata kunci : efektivitas, citra, korelasional

F Adriani, IA Ratnamulyani, Agustini. 2015. Efektivitas Kegiatan Humas Pemerintah Kota Bogor dan Citra Humas Dimata Publik Eksternal. Jurnal Komunikatio 2(1): Halaman 25-43. 


\section{PENDAHULUAN}

Setiap kegiatan Humas lembaga, organisasi, perusahaan dan badan usaha pasti melakukan upaya-upaya yang dapat membentuk pencitraan yang baik terhadap lembaga tersebut. Hampir seluruh instansi pemerintah kini memiliki kantor Humas, divisi yang diharapkan terampil melakukan pembangunan citra, jembatan pemerintah dengan masyarakat, serta penghubung pemerintah dengan pers. Efektivitas kegiatan Humas dapat dilihat dari kegiatan dan program-prograam Humas yang telah di jalankan. Program Humas yang berhasil melibatkan tiga faktor: kebijaksanaan, pelaksanaan kebijaksanaan tersebut, dan intrepretasi secara peka mengenai peristiwa-peristiwa yang berdasarkan pada komunikasi dua arah (dalam Frazier Moore, 2005:1). Oleh karena itu, keberadaan Humas yang efektif di pemerintahan sangat diperlukan karena Humas Pemerintahan menjadi ujung tombak dalam kelangsungan jalannya pemerintahan dalam menghadapi aspirasi masyarakat.

Menurut Emerson (dalam Handayaningrat 1996:16) bahwa "Efektivitas merupakan pengukuran dalam arti tercapainya sasaran atau tujuan yang telah ditentukan". Untuk menentukan apakah kegiatan-kegiatan Humas itu sudah efektif atau belum, Humas harus mencapai tujuan yang diharapkan. Jadi, apabila tujuan yang diharapakan oleh Humas tercapai kegiatan Humas tersebut dapat dikatakan sudah efektif. Dilapangan upaya peningkatan profesionalisme Humas Pemerintah masih banyak menemui kendala, baik dalam bidang operasional maupun Sumber Daya Manusia (SDM), yang lebih memprihatinkan lagi kondisi SDM Humas Pemerintahan sebagian besar belum memenuhi kualifikasi sebagai petugas humas yang professional. Peran Humas pada intinya adalah membina kesinambungan hubungan komunikasi timbal balik antara lembaga khususnya manajemen dengan publik internal dan eksternal.

Bagian Humas Pemerintah Kota Bogor merupakan salah satu bagian dari pemerintahan kota Bogor yang senantiasa memberikan pelayanan kepada publik, baik itu dari kalangan pers media massa lokal maupun luar kota Bogor, komunitas dapat dikategori kedalam masing-masing profesi seperti, komunitas pecinta alam, Lembaga Swadaya Masyarakat (LSM antikorupsi, LSM lingkungan dll) dan perhimpunan mahasiswa, masyarakat umum serta instansi-instansi yang berada dilingkungan pemerintahan kota Bogor sebagian besar datang untuk memohon informasi. Adapun informasi yang dibutuhkan beragam, tidak hanya sebatas reales berita, data seputar kehumasan, keuangan daerah, proyek-proyek di pemerintahan daerah dan lain-lain tetapi juga ingin memperoleh informasi lebih terkait dengan UU KIP (undangundang keterbukaan informasi publik). Dari semuanya yang rutin datang untuk meminta informasi kepada Humas adalah pers media massa lokal maupun luar kota Bogor dan perhimpunan mahasiswa karena informasi yang dibutuhkan misalnya berita, isu-isu pemerintahan kota Bogor bersumber dari Humas. Humas tidak hanya memberikan informasi kepada publik, tetapi Humas juga membutuhkan informasi dari luar Pemkot (eksternal) untuk keperluan informasi bagian Humas tersebut.

Humas pemerintah kota Bogor sejatinya melakukan kegiatan dan program sesuai dengan visi dan misi Humas itu sendiri yaitu sebagai sarana informasi, penyusun kebijakan pemerintah dan pelayanan kepada publik. Efektivitas dari kegiatan dan program Humas tersebut dapat dilihat apabila semuanya sudah dilaksanakan dengan baik sebagaimana mestinya. Oleh karena itu untuk mencapai tujuan Humas yang efektif, Humas Pemkot dibagi menjadi dua subbagian : 1. Kasubag pemberitaan, 2. Kasubag dokumentasi dan publikasi. Kedua bagian tersebut diharapkan mampu menjalankan serangkaian kegiatan Humas dengan baik. Staff Bagian Humas pemerintah kota Bogor melakukan kegiatan sesuai dengan bagiannya masing-masing. Kegiatan bagian Humas pemerintah kota Bogor yang rutin dilakukan setiap hari adalah apel pagi dengan Walikota, staff dari instansiinstansi yang berada dilingkungan pemerintah kota Bogor dan membuat rekapitulasi berita dari koran dari berbagai media massa lokal yang masuk ke Humas setiap harinya. Selain itu, kegiatan yang rutin juga dilakukan adalah dokumentasi dan publikasi kegiatan Walikota atau yang mewakili atas nama pemerintah kota Bogor, membuat press reales. Kegiatan dokumentasi dan publikasi tersebut dilakukan berdasarkan jadwal kegiatan Walikota yang diberikan oleh bagian protokoler pemerintah kota Bogor. Kegiatan Humas pemerintah kota 
Bogor yang lainnya adalah mengadakan kerjasama dengan berbagai media massa baik cetak maupun elektronik (Tv Megaswara, radio kisi fm, lesmana, RRI) yang lokal (Radar, Metropolitan, Lingkar Bogor dan lain sebagainya) maupun diluar kota Bogor (Republika dan lain-lain).

Kegiatan Humas dalam rangka penyebarluasan informasi pembangunan daerah dilakukan dengan cara jumpa pers. Hal ini dijelaskan Kasubag pemberitaan Edi Sudjadi (wawancara tgl 16 April 2012) : "Sepanjang tahun 2011, telah dilaksanakan empat kali pelaksanaan jumpa pers dengan mengangkat berbagai tema mulai dari persiapan Idul Fitri, pengawasan hewan qurban, sosialisasi PIN, sampai dialog akhir tahun. Narasumber yang hadir adalah perwakilan dari SKPD terkait tema". Selain itu, dilakukan juga dialog radio (kisi fm, Lesmana fm, RRI) dan televisi (Megaswara) setiap beberapa minggu sekali.Untuk program peningkatan SDM dibidang Komunikasi dan Informasi Humas Pemkot mengadakan rapat BAKOHUMAS (Badan Koordinasi Kehumasan) setiap tiga bulan sekali dan lokakarya Humas tujuannya untuk meningkatkan pelayanan dibidang kehumasan. Humas Pemkot juga mengadakan program pengembangan Komunikasi, Informasi dan Media Massa dengan menerbitkan media internal yaitu bulletin Kalawarta untuk memperkuat sosialisai kebijakan dan kegiatan dilingkungan pemerintah kota Bogor. Humas juga mengelola informasi kepada publik melalui website resmi pemerintah kota Bogor (www.pemerintahkotabogor.go.id) seperti yang telah dijelaskan oleh staff Humas Abdul Manan (wawancara 26 April 2012) : " bahwa satu fokus utama kehumasan di tahun 2011 adalah memperkuat up dating berita di website Kota Bogor. Dengan up dating yang dilakukan secara berkesinambungan tersebut diharapkan akan menarik minat banyak orang untuk mengunjungi website kota Bogor".

Kegiatan-kegiatan Humas diatas merupakan upaya-upaya Humas untuk mendapatkan citra yang positif dimata masyarakat eksternal. Citra merupakan sasaran utama Humas, setiap kegiatan yang dilakukan Humas untuk mendapatkan respon yang baik dari masyarakat. Perkembangan komunikasi tidak memungkinkan lagi bagi Humas untuk menutupi suatu fakta, baik itu fakta baik maupun fakta buruk tentang pemerintahan.
Oleh karena itu, Humas kini jauh dituntut untuk mampu menjadikan orang lain untuk memahami suatu pesan, demi menjaga reputasi atau citra instanti yang diwakilinya. Apabila seluruh kegiatan yang dilakukan Humas efektif maka citra yang diperoleh oleh Humas positif. Sebaliknya apabila kegiatan tersebut masih belum efektif berarti Humas harus meningkatkan kualitas kegiatan tersebut agar memperoleh citra yang positif dan tujuan yang diharapkan. Humas Pemerintahan tidak hanya mampu membangun dan mempertahankan citra positif saja, tetapi harus ada upaya perbaikan sistem yang berkaitan dengan personalia Humas itu sendiri. Kondisi dan kemampuan Humas akan berdampak langsung pada kegiatan yang mereka lakukan.

Meskipun secara struktural, bagian Humas pada jajaran Pemerintah Kota Bogor sudah cukup proposional bila dikaitkan dengan birokrasi pemerintah, namun sekilas profesionalisme masih belum begitu sesuai dengan standar kompetensi Humas pemerintahan. Idealnya Humas membina komunikasi dua arah yang dinamis dan berkesinambungan dengam publiknya. Namun berdasarkan pengamatan bagian Humas Pemerintah Kota Bogor masih kurang melakukan komunikasi dua arah. Hal ini dibuktikan dengan pemberian feedback kepada masyarakat tidak secara langsung. Kurangnya spesialisasi kehumasan yang ada di jajaran Pemerintah Kota Bogor ini disebabkan sistem mutasi yang sering terjadi, mutasi Pegawai Negeri Sipil (PNS) di jajaran Pemerintah Kota Bogor yang sebenarnya baik untuk penyegaran cenderung dilakukan tanpa melihat latar belakang pendidikan dan kompetensi yang dimiliki sehingga tugas-tugas Humas terlaksana tidak efektif. Penulis tertarik untuk meneliti di Bagian Humas kota Bogor karena ingin mengetahui apakah selama ini kegiatankegiatan yang telah dilakukan oleh Humas pemerintah kota Bogor sudah efektif, dan bagaimana citra yang didapatkan oleh Humas. Oleh karena itu penulis menetapkan judul penelitian "Efektivitas Kegiatan Humas Pemerintah Kota Bogor dan Citra Humas di Mata Publik Eksternal".

Berdasarkan uraian diatas, maka dapat dirumuskan permasalahan penelitian sebagai berikut: (1) Bagaimana efektifitas kegiatan Humas Pemerintah Kota Bogor?, (2) Bagaimana citra Humas Pemerintah Kota Bogor di mata publik eksternal, (3) Bagaimana hubungan 
antara efektifitas kegitan Humas dengan citra Humas?, Adapun Tujuan Penelitian Adalah (1) Untuk mengetahui seberapa efektif kegiatan Humas pemerintah Kota Bogor?, (2) Untuk mengetahui bagaimana citra Humas pemerintah Kota Bogor dimata publik eksternal?, (3) Untuk mengetahui hubungan antara efektivitas kegiatan Humas dengan citra Humas?.

Kegunaan penelitian ini adalah Dapat memberikan kontribusi pemikiran tentang penelitian Humas Pemerintah Kota Bogor selanjutnya, memberikan sumbangsih pikiran mengenai pentingnya pembentukan citra kepada publik melalui aktivitas-aktivitas Humas. Selain itu sebagai tambahan wawasan, ilmu pengetahuan dan pengalaman peneliti guna memperoleh ilmu dibidang kehumasan khususnya Humas Pemerintah Kota Bogor. Sebagai masukan kepada Pemerintah Kota Bogor untuk merumuskan strategi komunikasi selanjutnya. Dan memberikan pemahaman kepada publik tentang Pemerintah Kota Bogor.

\section{KERANGKA PEMIKIRAN}

Efektivitas kegiatan Humas merupakan suatu ukuran yang menyatakan seberapa baik kegiatan Humas yang dilakukan sehingga mencapai hasil yang diharapkan. Ini berarti apabila suatu kegiatan dapat diselesaikan dengan perencanaan yang baik maka seluruh kegiatan Humas ini dapat dikatakan efektif. Begitu juga dengan bagian Humas pemerintah kota Bogor. Kegiatan Humas di pemerintah Kota Bogor dibagi menjadi dua sub bagian yaitu dokumentasi \& publikasi dan pemberitaan. Di bagian Dokumentasi dan publikasi ini Humas mempunyai tugas yaitu klipping koran, transkrip pidato, press realeas dan bulletin. Sedangkan dibagian pemberitaan tugas Humas yaitu media relation, konfrensi pers. Kegiatan Humas seperti ini sudah rutin dijalani oleh bagian Humas pemerintah Kota Bogor setiap harinya. Kegiatan Humas dapat dikatakan efektif apabila kegiatan tersebut dapat mencapai tujuan dan hasil yang diharapkan, begitu pula sebaliknya.

Seluruh kegiatan yang dilakukan oleh Humas merupakan salah satu bentuk kegiatan untuk memperoleh citra yang baik dimata publik. Citra Humas sendiri dapat dibentuk berdasarkan sikap Humas, pelayanan, dan Informasi yang diberikan oleh Humas kepada publik. Publik yang dimaksud adalah publik eksternal yaitu orang-orang yang berada diluar lingkungan Humas karena termasuk dalam sasaran Humas untuk memperoleh citra positif dan yang bisa menilai kegiatan Humas yang ada. Citra yang baik dapat dinilai jika seluruh kegiatan Humas tersebut sudah efektif dan mendapatkan hasil yang diharapkan. Oleh karena itu, para staff Humas diharapkan mampu untuk membangun citra yang dipositif dimata publik. Dalam penelitian ini yang menjadi variabel bebas adalah efektivitas kegiatan Humas dan variabel terikat adalah citra Humas dimata publik eksternal. Penelitian ini dilakukan untuk mengetahui bagaimana efektivitas kegian Humas, bagaimana citra Humas di mata publik eksternal, dan bagaimana hubungan efektivitas kegiatan dengan citra Humas. 
Gambar 1. Kerangka Pemikiran

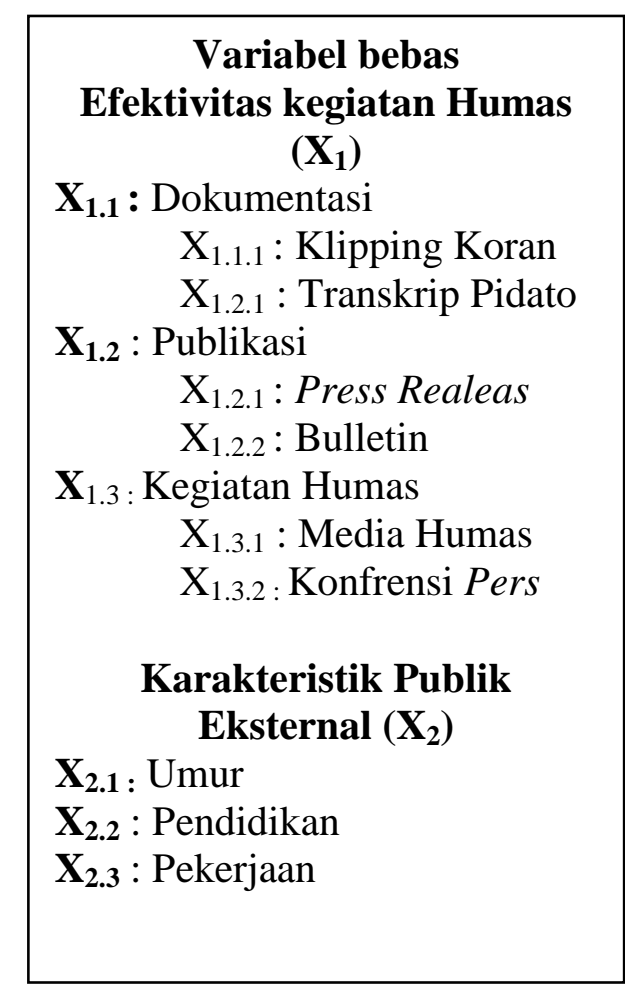

\section{Hipotesis Penelitian}

Hipotesis dalam penelitian merupakan jawaban sementara terhadap rumusan masalah pada suatu penelitian (Sugiono, 2009:85). Dalam penelitian ini hipotesis yang diajukan oleh peneliti adalah sebagai berikut:

\section{METODE PENELITIAN}

Penelitian ini, metode yang digunakan adalah metode korelasional. metode korelasional sebenarnya kelanjutan dari metode deskriptif. dengan metode deskriptif, kita menghimpun data, menyusunnya secara sistematis, faktual dan cermat. Metode korelasional digunakan untuk: (1) mengukur hubungan di antara berbagai variable, (2) meramalkan variabel tak bebas dari pengetahuan kita tentang variabel bebas, dan (3) meratakan jalan untuk membuat rancangan pencarian eksperimental (rakhmat, metode penelitian komunikasi, 2009).

Penelitian korelasi adalah penelitian yang melihat hubungan antara dua variabel atau lebih yang kemudian diteliti untuk melihat

$\longrightarrow$\begin{tabular}{c|c|}
\hline Variabel Terikat \\
Citra Humas di \\
Mata Publik \\
Eksternal (Y) \\
$\mathbf{Y}_{1}:$ Pelayanan \\
$\mathbf{Y}_{2}:$ Informasi
\end{tabular}

Ho : Efektivitas kegitan Humas Pemerintah Kota Bogor tidak berhubungan terhadap citra Humas di mata publik eksternal

Ha : Efektivitas kegitan Humas Pemerintah Kota Bogor berhubungan terhadap citra Humas di mata publik eksternal

hubungan yang terjadi diantara mereka tanpa mencoba untuk merubah atau mengadakan perlakuan terhadap variabel-variabel tersebut.

Penelitian yang digunakan adalah penelitian kuantitatif. kuantitatif adalah riset yang menggambarkan atau menjelaskan suatu masalah yang hasilnya dapat digeneralisasikan. dengan demikian tidak terlalu mementingkan kedalaman data atau analisis. peneliti lebih mementingkan aspek keluasan data sehingga data atau hasil riset dianggap merupakan representasi dari seluruh populasi. penelitian kuantitaif tidak boleh membuat batasan konsep maupun alat ukur data sekehendak sendiri. semua harus objektif dengan diuji terlebih dahulu apakah batasan konsep dan alat ukurnya sudah memenuhi prinsip reliabilitas dan validitas. (kriyantono, 2010). Penelitian ini dilakukan di Bagian Humas Pemerintah Kota 
Bogor. Penelitian ini dilakukan pada bulan Maret sampai dengan bulan Juni 2012. Sampel penelitian ini sebanyak 47 orang

\section{HASIL DAN PEMBAHASAN}

\section{Gambaran Umum Pemerintah Kota Bogor}

Kota Bogor mempunyai sejarah yang panjang dalam pemerintahan, mengingat sejak zaman Kerajaan Pajajaran sesuai dengan bukti-bukti yang ada seperti dari Prasasti Batu Tulis, nama-nama kampung dikenal dengan nama Lawanggintung, Lawang Saketeng, Jerokuta, Baranangsiang dan Leuwi Sipatahunan diyakini bahwa Pakuan sebagai Ibukota Pajajaran terletak di Kota Bogor. Pakuan sebagai pusat Pemerintahan Pajajaran terkenal pada pemerintahan Prabu Siliwangi (Sri Baginda Maharaja) yang penobatannya tepat pada tanggal 3 Juni 1482, yang selanjutnya hari tersebut dijadikan hari jadi Bogor karena sejak tahun 1973 telah ditetapkan oleh DPRD Kabupaten dan Kota Bogor sebagai hari jadi Bogor dan selalu diperingati setiap tahunnya sampai sekarang.

Sebagai akibat penyerbuan tentara Banten ke Pakuan Pajajaran catatan mengenai Kota Pakuan tersebut hilang, baru terungkap kembali setelah datangnya rombongan ekspidisi orang-orang Belanda yang dipimpin oleh Scipio dan Riebeck pada tahun 1687, mereka meneliti Prasasti Batutulis dan situssitus lainya yang meyakini bahwa di Bogorlah terletak pusat Pemerintahan Pakuan Pajajaran. Pada tahun 1745 Gubernur Jendral Hindia Belanda pada waktu itu bernama Baron Van Inhoff membangun Istana Bogor.

Seiring dengan pembangunan jalan Raya Daenless yang menghubungkan Batavia dengan Bogor, sehingga keadaan Bogor mulai bekembang. Pada masa pendudukan Inggris yang menjadi Gubernur Jendralnya adalah Thomas Rafless, beliau cukup berjasa dalam mengembangkan Kota Bogor. Istana Bogor direnofasi dan sebagian tanahnya dijadikan Kebun Raya (Botanical Garden), beliau juga memperkejakan seorang Planner yang bernama Carsens yang menata Bogor sebagai tempat peristirahatan yang dikenal dengan Buitenzoorg. Setelah Pemerintahan kembali kepada Hindia Belanda pada tahun1903, terbit Undang-undang Desentralisasi yang bertujuan menghapus sistem pemerintahan tradisional diganti dengan sistem administrasi pemerintahan modern sebagai realisasinya dibentuk Staadsgemeente diantaranya:

1) Gemeente Batavia (S. 1903 No.204 )

2) Gemeente Meester Cornelis ( S. 1905 No.206)

3) Gemeente Buitenzoorg ( S. 1905 No.208)

4) Gemeente Bandoeng ( S. 1906 No.121)

5) Gemeente Cirebon ( S. 1905 No.122 )

6) Gemeente Soekabumi ( S. 1914 No.310 )

Pembentukan Gemeente tersebut bukan untuk kepentingan penduduk Pribumi tetapi untuk kepentingan orang-orang Belanda dan masyarakat Golongan Eropa dan yang dipersamakan (yang menjadi Burgermeester dari Staatsgemeente Buitenzoorg selalu orangorang Belanda dan baru tahun 1940 diduduki oleh orang Bumiputra yaitu Mr. Soebroto). Pada tahun 1922 sebagai akibat dari ketidakpuasan terhadap peran desentralisasi yang ada maka terbentuklah Bestuursher Voorings Ordonantie atau Undang-undang perubahan tata Pemerintahan Negeri Hindia Belanda (Staatsblad 1922 No. 216), sehinga pada tahun 1992 terbentuklah Regentschaps Ordonantie (Ordonantie Kabupaten) yang membuat ketentuan-ketentuan daerah Otonomi Kabupaten (Staatsblad 1925 No. 79).

Propinsi Jawa Barat dibentuk pada tahun 1925 (Staatsblad 1924 No. 378 bij Propince West Java) yang terdiri dari 5 keresidenan, 18 Kabupaten (Regentscape) dan Kotapraja (Staads Gemeente), dimana Buitenzoorg (Bogor) salah satu Staads Gemeente di Propinsi Jawa Barat di bentuk berdasarkan (Staatsblad 1905 No. 208 jo. Staatsblad 1926 No. 368), dengan pripsip Desentralisasi Modern dimana kedudukan Bugermeester menjadi jelas. Pada masa pendudukan Jepang kedudukan pemerintahan di Kota Bogor menjadi lemah karena pemerintahan dipusatkan pada tingkat keresidenan yang berkedudukan di Kota Bogor. Pada masa ini nama-nama lembaga pemerintahan berubah namanya yaitu: Keresidenan menjadi Syoeoe, Kabupaten/Regenschaps menjadi ken, Kota/Staads Gemeente menjadi $\mathrm{Si}$, Kewedanaan menjadi/Distrik menjadi Gun, Kecamatan/Under Districk menjadi Soe dan desa menjadi Koe. 
Pada masa setelah kemerdekaan, yaitu setelah pengakuan kedaulatan RI Pemerintahan di Kota Bogor namanya menjadi Kota Besar Bogor yang dibentuk berdasarakan Udang-undang Nomor 16 Tahun 1950. Selanjutnya pada tahun 1957 nama pemerintahan berubah menjadi Kota Praja Bogor, sesuai dengan Undang-undang Nomor.
1Tahun 1957, kemudian dengan Undangundang Nomor 18 tahun 1965 dan Undangundang No. 5 Tahun 1974 berubah kembali menjadi Kotamadya Daerah Tingkat II Bogor. Dengan diberlakukanya Undang-undang Nomor 22 Tahun 1999, Kotamadya Daerah Tingkat II Bogor dirubah menjadi Kota Bogor.

\subsection{Lambang Kota Bogor}

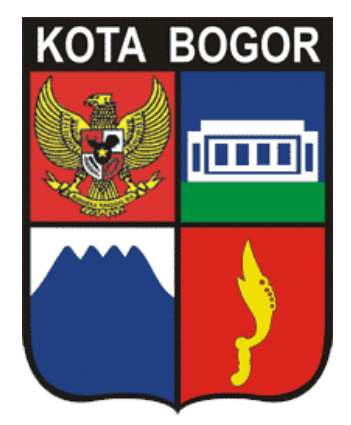

Terdapat warna-warna : emas, merah, biru dan hijau.

Gambar 2. Lambang Kota Bogor

Arti tiap lambang:

1. Kiri atas, Burung Garuda kuning emas merupakan Lambang Negara.

2. Kanan atas, di Kota Bogor terletak Istana Bogor yang dinyatakan dengan lukisan istana Warna Perak.

3. Kiri bawah, Kota Bogor, tak dapat dilepaskan dari bayangan Gunung Salak dilukiskan dalam simbol gunung dengan empat buah puncaknya.

4. Kota Bogor adalah suatu pusaka dari Kerajaan Pajajaran, hal ini dilukiskan dengan bentuk Kujang.

\section{Visi Dan Misi Kota Bogor}

Visi kota Bogor 2010-2014 adalah "Kota Perdagangan dengan Sumber Daya Manusia Produktif dan Pelayanan Prima". Untuk mewujudkan visi tersebut, maka ditetapkan misi kota Bogor yaitu:

1) Mengembangkan perekonomian masyarakat yang bertumpu pada kegiatan jasa perdagangan.

2) Mewujudkan kota yang bersih dengan sarana prasarana transportasi yang berkualitas.

3) Meningkatkan kualitas sumber daya manusia dengan penekanan pada penuntasan wajib belajar 12 tahun, serta peningkatan kesehatan dan keterampilan masyarakat.

4) Peningkatan pelayanan publik dan partisipasi masyarakat. 


\section{Struktur Organisai Sekretariat Daerah Kota Bogor}

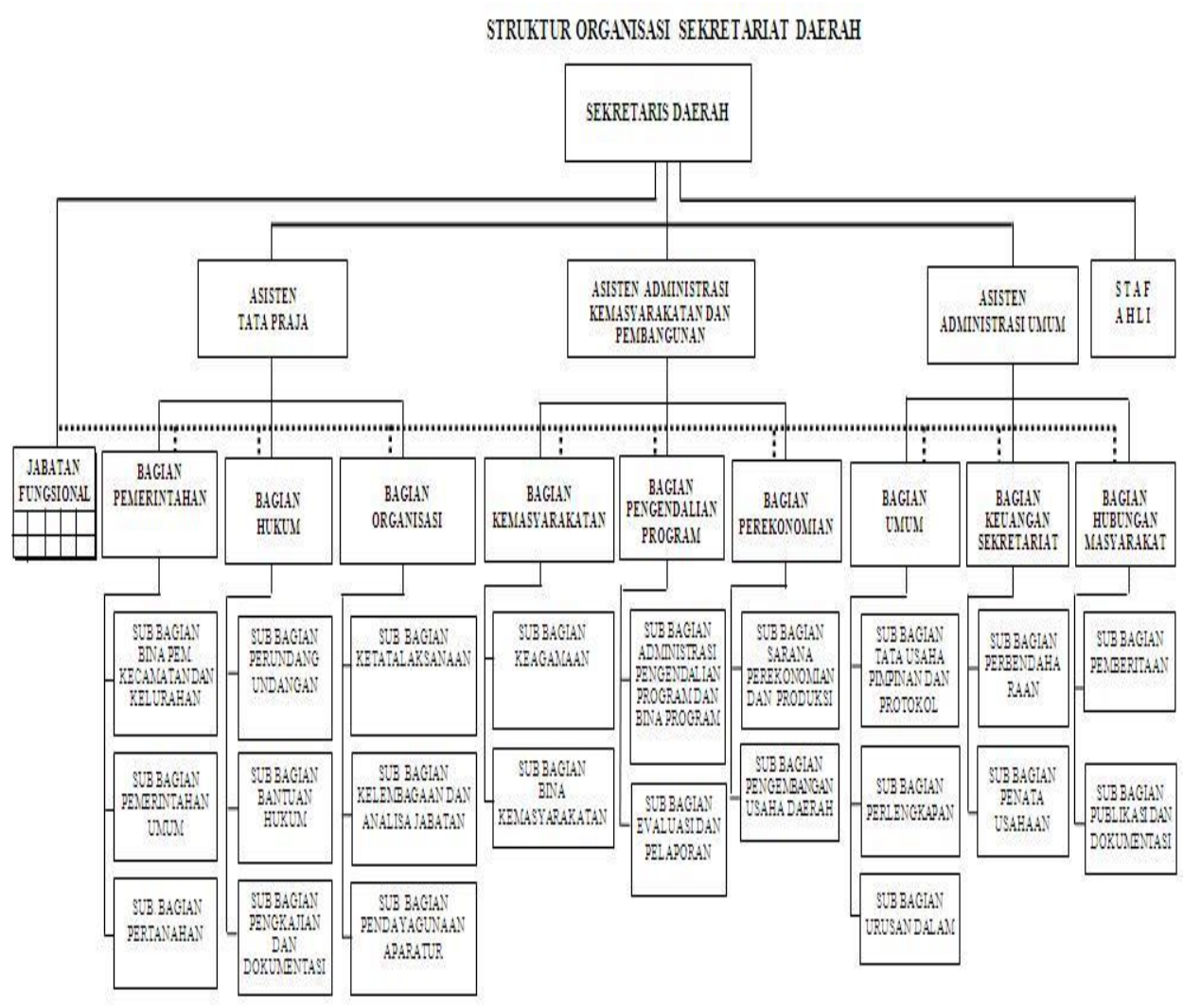

Gambar 3. Struktur Organisasi Pemkot Bogor

\section{Bagian Humas Pemerintah Kota Bogor}

Bagian Hubungan Masyarakat dipimpin oleh seorang Kepala Bagian yang mempunyai tugas pokok melaksanakan sebagian fungsi Asisten Administrasi Umum di bidang kehumasan. Fungsi Bagian Humas Pemerintah Kota Bogor sebagai berikut:

1. Penyusunan rencana dan program kerja di bidang hubungan masyarakat;

2. Perumusan kebijakan di bidang kehumasan yang meliputi hubungan masyarakat;

3. Pembinaan dan pengkoordinasian kegiatan di bidang hubungan masyarakat;

4. Pengevaluasian dan pelaporan kegiatan.

Bagian Humas pemerintah kota Bogor yang menjadi tempat pelaksanaan penelitian terletatak dilantai I Gedung Sekretariat Kota Bogor serta dikepalai oleh Kepala Bagian Humas Sekretariat Daerah Kota Bogor Drs. H. Asep Firdaus, MM. Kepala Bagian Humas membawahi beberapa kepala sub bagian untuk membantu pelaksanaan tugas-tugas kehumasan, yaitu:

1. Sub Bagian Pemberitaan. Sub Bagian Pemberitaan dipimpin oleh seorang Kepala Sub Bagian yang mempunyai tugas pokok melaksanakan sebagian fungsi Bagian Hubungan Masyarakat di bidang pemberitaan, yaitu

1) Penyiapan bahan dan penyusunan petunjuk teknis di bidang pemberitaan;

2) Penyiapan draft kebijakan di bidang pemberitaan;

3) Pengkoordinasian kegiatan dibidang pemberitaan;

4) Pelaksanaan kegiatan pemberitaan;

5) Pelaksanaan administrasi dan dokumentasi kegiatan;

6) Pengevaluasian dan pelaporan kegiatan.

2. Sub Bagian Publikasi dan Dokumentasi. Sub Bagian Publikasi dan Dokumentasi dipimpin oleh seorang Kepala Sub 
Bagian yang mempunyai tugas pokok melaksanakan sebagian fungsi Bagian Hubungan Masyarakat di bidang publikasi dan dokumentasi, yaitu:

1. Penyiapan bahan dan penyusunan petunjuk teknis di bidang publikasi dan dokumentasi;

2. Penyiapan draft kebijakan di bidang publikasi dan dokumentasi;

3. Pengkoordinasiaan kegiatan di bidang publikasi dan dokumentasi kegiatan Walikota, Wakil Walikota, Sekretaris Daerah dan Pejabat lainnya;

4. Pelaksanaan administrasi dan dokumentasi kegiatan;

5. Pengevaluasian dan pelaporan kegiatan.

\section{Karakteristik Publik Eksternal yang menilai Efektivitas Humas}

Sebelum mengetahui lebih jauh mengenai hasil penelitian di lapangan, perlu diketahui karakteristik publik eksternal yang menjadi objek penelitian. Publik eksternal yang menjadi objek penelitian adalah pengunjung bagian Humas pemerintah kota Bogor dan yang ingin mendapatkan informasi dan pelayanan dari Humas, instansi serta wartawan dari media cetak lokal. Hal tersebut dikarenakan peneliti ingin mengetahui tanggapan dari publik eksternal mengenai kegiatan dan citra Humas pemerintah kota Bogor. Untuk mengetahui tingkat pendidikan dan pekerjaan publik eksternal dapat dilihat pada tabel berikut ini:

Tabel 1. Karakteristik Publik Eksternal

\begin{tabular}{|c|c|c|}
\hline Pendidikan & Jumlah Responden & \% \\
\hline SD & 0 & 0 \\
\hline SMP/Sederajat & 3 & $6 \%$ \\
\hline SMA/Sederajat & 20 & $43 \%$ \\
\hline Diploma/SI & 24 & $51 \%$ \\
\hline Total & 47 & $100 \%$ \\
\hline Pekerjaan & Jumlah & $19 \%$ \\
\hline PNS & 9 & $13 \%$ \\
\hline Wartawan & 6 & $30 \%$ \\
\hline Swasta & 14 & $21 \%$ \\
\hline LSM & 10 & $17 \%$ \\
\hline Mahasiswa & 8 & $100 \%$ \\
\hline Total & 47 & $\%$ \\
\hline
\end{tabular}

Berdasarkan data pada Tabel 3 diatas, diketahui jumlah pendidikan terakhir responden adalah SMA sebanyak 43\% dan Diploma/S1 sebanyak 51\%. Dengan latar belakang pendidikan tersebut berpengaruh pada karakteristik responden yang memberikan tanggapan tentang efektivitas dan citra Humas pemerintah kota Bogor. Sedangkan tingkat pekerjaan responden sebagian besar berwiraswasta yaitu sebanyak 30\%. Dari tingkat pekerjaan responden dapat dilihat 
bahwa pengunjung terbesar Humas pemerintah kota Bogor bekerja di swasta.

\section{Analisis Deskriptif Efektivitas Kegiatan Humas Pemerintah Kota Bogor dan Citra Humas Dimata Publik Eksternal}

Untuk mengetahui gambaran tentang efektivitas kegiatan Humas dan citra Humas di pemerintah Kota Bogor dapat ditunjukan dengan jumlah pengunjung bagian Humas yaitu 89 orang, dan beberapa tabel tanggapan responden tentang efektivitas kegiatan dan citra Humas. Jumlah responden dalam penelitian ini dari 89 menjadi 47 responden yang diambil secara purposive. Sedangkan jawaban tersebut disajikan dalam bentuk tabulasi yang berupa pertanyaan terstruktur dengan didasarkan pada indikator komponen kegiatan sebagai berikut:

\section{Variabel Efektivitas Kegiatan Humas Pemerintah Kota Bogor}

\section{Dokumentasi}

Penulis meminta tanggapan responden tentang kegiatan dokumentasi yang dilakukan oleh Humas pemerintah kota Bogor. Dokumentasi bertugas meliput seluruh kegiatan pemerintah kota Bogor ataupun yang mewakili atas nama pemerintah kota Bogor. Untuk itu kegiatan ini perlu dinilai bagaimana pelaksanaannya selama ini agar dapat dilihat seberapa efektif kegiatan tersebut. Hal ini dapat dilihat pada Tabel 2:

Tabel 2. Efektivitas kegiatan dokumentasi

\begin{tabular}{|c|c|c|c|c|c|}
\hline No & Jawaban & $\boldsymbol{F}$ & $\mathbf{X}$ & $f(x)$ & $\sum f(\mathrm{x}) / \mathrm{N}$ \\
\hline A & Sangat Setuju & 15 & 5 & 75 & \multirow{6}{*}{4,02} \\
\hline B & Setuju & 20 & 4 & 80 & \\
\hline C & Ragu-ragu & 10 & 3 & 30 & \\
\hline D & Tidak Setuju & 2 & 2 & 4 & \\
\hline $\mathbf{E}$ & Sangat Tidak Setuju & 0 & 1 & 0 & \\
\hline & Jumlah & 47 & & 189 & \\
\hline
\end{tabular}

Dari Tabel 2 tentang tanggapan responden tentang kegiatan dokumentasi, diperoleh angka penafsiran (M) sebesar 4,02 yang berada dalam kategori "baik". Jawaban dari 47 responden, 15 orang responden menjawab sanagat setuju, 20 orang responden menjawab setuju, 10 orang responden, menjawab ragu-ragu, 2 orang responden menjawab tidak setuju, menjawab sangat tidak setuju tidak ada (0). Data diatas menunjukan bahwa kegiatan dokumentasi yang dilakukan oleh Humas sudah dilaksanakan dengan baik. Untuk itu, kegiatan yang selama ini dilakukan perlu dilihat bagaimana pelaksanaannya selama ini. Untuk mempermudah, diuraikan menjadi beberapa indikator yaitu sebagai berikut:

1) Klipping Koran

Penulis meminta tanggapan tentang pengklippingan koran, klipping koran merupakan kegiatan Humas dalam membuat klipping pemberitaan pemerintah kota Bogor dimedia massa cetak baik itu positif maupun negatif. Selanjutnya dijilid dan dikategorikan berdasarkan periode. Jawaban responden tentang tanggapan mengenai pengklippingan koran dapat dilihat pada tabell dibawah ini: 


\begin{tabular}{|c|c|c|c|c|c|}
\hline No & Jawaban & $F$ & $\mathbf{X}$ & $f(x)$ & $\sum f(\mathrm{x}) / \mathrm{N}$ \\
\hline $\mathbf{A}$ & Sangat Setuju & 0 & 5 & 0 & \multirow{6}{*}{3,17} \\
\hline B & Setuju & 15 & 4 & 60 & \\
\hline C & Ragu-ragu & 25 & 3 & 75 & \\
\hline D & Tidak Setuju & 2 & 2 & 14 & \\
\hline $\mathbf{E}$ & Sangat Tidak Setuju & 0 & 1 & 0 & \\
\hline & Jumlah & 47 & & 149 & \\
\hline
\end{tabular}

Dari Tabel 3 tanggapan tentang kegiatan klipping koran di Humas diperoleh angka penafsiran sebesar 3,17 yang berasda dikategori cukup. Jawaban dari 47 responden, menjawab sangat setuju tidak ada, 15 orang menjawab setuju, 25 orang menjawab raguragu, 2 orang menjawab tidak setuju, menjawab sangat tidak setuju tidak ada. Hal ini menunjukan bahwa tidak semua responden mengetahui tentang kegiatan tersebut. Dari hasil wawancara dilapangan, banyak responden yang bertanya bagaimana proses pengklipingan koran tersebut. Sebagian dari responden ada yang melihat bentuk dari klipping tersebut, sebagian lagi belum pernah melihat sama sekali. Hasil wawancara dengan salah satu staff Humas Abdul Manan (wawancara 6 Juni 2012) :"kami tidak mempublikasikan hasil pengklippingan koran kepda masyarakat, karena itu merupakan arsip Humas. Tetapi apabila ada yang memerlukan data dan ingin melihat hasil klippingan koran tersebut silahkan saja".

\section{2) Transkrip Pidato}

Penulis meminta tanggapan tentang transkrip pidato Walikota yang dibuat oleh Humas. Transkrip pidato merupakan salah satu kegiatan Bagian Humas pemerintah kota Bogor yang membuat transkrip pidato Walikota Bogor. Transkrip pidato ini biasanya berbentuk naskah pidato yang siap untuk dibacakan. Jawaban responden tentang kegiatan ini dapat dilihat pada tabel dibawah ini:

Tabel 4: Efektivitas kegiatan transkrip pidato

\begin{tabular}{|c|c|c|c|c|c|}
\hline No & Jawaban & $F$ & $\mathbf{X}$ & $f(x)$ & $\sum f(\mathrm{x}) / \mathrm{N}$ \\
\hline $\mathbf{A}$ & Sangat Setuju & 9 & 5 & 45 & \multirow{6}{*}{3,38} \\
\hline B & Setuju & 23 & 4 & 72 & \\
\hline C & Ragu-ragu & 12 & 3 & 36 & \\
\hline D & Tidak Setuju & 3 & 2 & 6 & \\
\hline $\mathbf{E}$ & Sangat Tidak Setuju & 0 & 1 & 0 & \\
\hline & Jumlah & 47 & & 159 & \\
\hline
\end{tabular}

Dari Tabel 4 diatas tanggapan responden tentang transkrip pidato yang dibuat oleh
Humas diperoleh angka penafsiran sebesar 3,38 yang berada dikategori baik. Jawaban dari 
47 responden, 9 orang menjawab sangat setuju, 23 orang menjawab setuju, 12 orang menjawab ragu-ragu, 3 orang menjawab tidak setuju, menjawab sangat tidak setuju tidak ada. Dari hasil wawancara dilapangan tidak semua semua responden menyatakan setuju jika transkrip pidato yang dibuat oleh Humas sudah baik, karena tidak semua melihat ataupun mendengar langsung pidato dari Walikota Bogor. Hanya pada acara tertentu dan pada waktu tertentu saja, karena tidak semua kegiatan Walikota Bogor bisa dihadiri oleh masyarakat umum.

\section{Publikasi}

Publikasi di Humas pemerintah kota Bogor bertugas meyusun bahan publikasi dari hasil liputan, membina hubungan dengan lembaga resmi dan masyarakat. Dalam sub variabel ini diuraikan menjadi beberapa indikator sebagai berikut :

\section{1) Press Realeas}

Penulis meminta tanggapan tentang press realeas yang dibuat oleh Humas, kemudian diterbitkan melalui website resmi pemerintah kota Bogor. Kegiatan ini hampir setiap hari dilakukan oleh Humas karena berita harus di publikasikan untuk pembaharuan informasi kepada masyarakat. Jawaban responden tentang kegiatan ini dapat dilihat pada tabel dibawah ini:

Tabel 5 Efektivitas kegiatan Press Realeas

\begin{tabular}{|c|c|c|c|c|c|}
\hline No & Jawaban & $F$ & $\mathbf{X}$ & $f(x)$ & $\sum f(\mathrm{x}) / \mathrm{N}$ \\
\hline A & Sangat Setuju & 0 & 5 & 0 & \multirow{6}{*}{3,29} \\
\hline B & Setuju & 23 & 4 & 92 & \\
\hline C & Ragu-ragu & 15 & 3 & 45 & \\
\hline D & Tidak Setuju & 9 & 2 & 18 & \\
\hline $\mathbf{E}$ & Sangat Tidak Setuju & 0 & 1 & 0 & \\
\hline & Jumlah & 47 & & 155 & \\
\hline
\end{tabular}

Dari Tabel 5 diatas tanggapan responden tentang kegiatan pembuatan press realeas oleh Humas diperoleh angka penafsiran sebesar 3,29 yang berada pada kategori cukup. Jawaban responden dari 47 responden, menjawab sangat setuju tidak ada, 23 orang menjawab setuju, 15 orang menjawab raguragu, 9 orang menjawab tidak setuju, menjawab tidak setuju tidak ada. Hal ini menunjukan kegiatan pembuatan press realeas di Humas belum cukup efektif. Dari hasil wawancara dengan responden, sebagian besar menyatakan bahwa berita yang dimuat di website terkadang kurang up to date karena lebih dulu terbit di media cetak. Sehingga mereka jarang sekali mengakses website resmi pemerintah kota Bogor.

\section{2) Bulletin}

Bulletin adalah media internal yang diterbitkan Bagian Humas Setdakot Bogor untuk memperkuat sosialiasi kebijakan dan kegiatan di lingkungan Pemerintah Kota Bogor yang frekuensi terbitnya sebulan sekali. Jawaban responden tentang kegiatan bulletin dapat dilihat pada tabel dibawah ini: 
Tabel 6. Tanggapan responden tentang bulletin

\begin{tabular}{|c|c|c|c|c|c|}
\hline No & Alternatif Jawaban & Frekuensi $(f)$ & Skor $(\mathrm{x})$ & $f(x)$ & $\frac{f(x)}{N}$ \\
\hline 1 & Sangat Setuju & 4 & 5 & 20 & \multirow{6}{*}{3,85} \\
\hline 2 & Setuju & 38 & 4 & 152 & \\
\hline 3 & Ragu-ragu & 2 & 3 & 3 & \\
\hline 4 & Tidak Setuju & 3 & 2 & 6 & \\
\hline 5 & Sangat Tidak Setuju & 0 & 1 & 0 & \\
\hline \multicolumn{2}{|r|}{ Jumlah (N) } & 47 & & 181 & \\
\hline
\end{tabular}

Berdasarkan Tabel 6 tentang tanggapan media internal Humas bulletin diperoleh angka penafsiran sebesar 3,38 yang berada pada kategori baik. Jawaban dari 47 responden, 4 orang responden menjawab sangat setuju, 38 orang responden menjawab setuju, 2 orang menjawab ragu-ragu, 3 orang menjawab tidak setuju, menjawab sangat tidak setuju tidak ada. Data diatas menunjukkan bahwa bulletin sebagai media Humas sudah terlaksana dengan baik.

\section{Kegiatan Humas}

Kegiatan setiap hari yang biasa dilakukan oleh seorang Humas dalam menjalankan tugas dan fungsi Humas Untuk memberikan citra yang baik dimata publik. Kegiatannya bisa berupa memberikan berita, mengadakan pameran pembangunan dan sebagainya sesuai prosedur yang ditetapkan oleh instansi pemerintahan daerah dan tidak berubah-ubah. Dalam sub variabel ini diuraikan menjadi beberapa indikator yaitu:

1. Media Humas yaitu perantara Humas dalam menyampaikan informasi ataupun pesan kepada publik. Jawaban dari responden tentang tanggapan media Humas dapat dilihat pada tabel berikut: 
Tabel 7. Tanggapan responden tentang media Humas

\begin{tabular}{|c|c|c|c|c|c|}
\hline No & Jawaban & $F$ & $\mathbf{X}$ & $f(x)$ & $\sum f(\mathrm{x}) / \mathrm{N}$ \\
\hline $\mathbf{A}$ & Sangat Setuju & 8 & 5 & 40 & \multirow{6}{*}{3,19} \\
\hline B & Setuju & 22 & 4 & 72 & \\
\hline C & Ragu-ragu & 7 & 3 & 18 & \\
\hline D & Tidak Setuju & 10 & 2 & 20 & \\
\hline $\mathbf{E}$ & Sangat Tidak Setuju & 0 & 1 & 0 & \\
\hline & Jumlah & 47 & & 150 & \\
\hline
\end{tabular}

Tabel 7 diatas tanggapan yang diberikan responden tentang media Humas memperoleh angka penafsiran sebesar 3,19 yang berada pada ketegori cukup. Jawaban dari 47 responden, 8 orang menjawab sangat setuju, 22 orang menjawab setuju, 7 menjawab ragu-ragu, 10 orang menjawab tidak setuju, menjawab sangat tidak setuju tidak ada. Hal ini menunjukan bahwa media Humas belum memenuhi harapan publik.
2. Konferensi Pers yaitu kegiatan Humas dalam mengadakan kegiatan dialog dengan wartawan. Jawaban responden tentang kegiatan ini dapat dilihat pada tabel dibawah ini:

Tabel 8: Efektivitas kegiatan konferensi pers

\begin{tabular}{|c|c|c|c|c|c|}
\hline No & Jawaban & $F$ & $\mathbf{X}$ & $f(x)$ & $\sum f(\mathrm{x}) / \mathrm{N}$ \\
\hline A & Sangat Setuju & 0 & 5 & 0 & \multirow{6}{*}{3,38} \\
\hline B & Setuju & 21 & 4 & 84 & \\
\hline C & Ragu-ragu & 23 & 3 & 69 & \\
\hline D & Tidak Setuju & 3 & 2 & 6 & \\
\hline $\mathbf{E}$ & Sangat Tidak Setuju & 0 & 1 & 0 & \\
\hline & Jumlah & 47 & & 159 & \\
\hline
\end{tabular}

Dari Tabel 8 diatas tanggapan yang diberikan responden tentang media Humas memperoleh angka penafsiran sebesar 3,38 yang berada pada ketegori cukup. Jawaban dari 47 responden, menjawab sangat setuju tidak ada, 21 orang menjawab setuju, 23 menjawab raguragu, 3 orang menjawab tidak setuju, menjawab sangat tidak setuju tidak ada. Hal ini menunjukan bahwa media Humas dinilai cukup baik. dari hasil wawancara dengan staff Humas diketahui bahwa kegiatan konferensi pers dilakukan paling banyak empat kali dalam satu tahun. 


\section{Variabel Citra Humas Pemerintah Kota Bogor}

Penulis meminta respon masyarakat tentang citra Humas pemerintah kota Bogor. Maksud dari citra Humas merupakan respon dari masyarakat terhadap kegiatan dan program Humas. Kemudian respon dari masyarakat tentang sikap. pelayanan dan informasi yang diberikan oleh Humas terhadap pengunjung Humas. untuk mempermudah, dalam variabel citra ini dibagi menjadi beberapa indikator dibawah ini :

\section{Pelayanan}

Penulis meminta respon tentang pelayanan yang diberikan oleh Humas terhadap pengunjung yang memerlukan pelayan informasi atau bantuan dari Humas. Jawaban dari reponden tentang pelayana dari Humas dapat dilihat pada tabel dibawah ini :

Tabel 9. Tanggapan tentang pelayanan Humas

\begin{tabular}{|c|c|c|c|c|c|}
\hline No & Jawaban & $F$ & $\mathbf{X}$ & $f(x)$ & $\sum f(\mathrm{x}) / \mathrm{N}$ \\
\hline A & Sangat Setuju & 2 & 5 & 10 & \multirow{6}{*}{2,70} \\
\hline B & Setuju & 20 & 4 & 60 & \\
\hline C & Ragu-ragu & 5 & 3 & 15 & \\
\hline D & Tidak Setuju & 20 & 2 & 40 & \\
\hline E & Sangat Tidak Setuju & 0 & 1 & 0 & \\
\hline & Jumlah & 47 & & 125 & \\
\hline
\end{tabular}

Dari Tabel 9 tanggapan tentang pelayanan yang diberikan oleh Humas memperoleh angka kriteria penafsiran sebesar 2,70 yang berada pada kategori cukup. Dimana frekuensi jawaban dari 47 responden, 2 orang menjawab sangat setuju, 20 orang menjawab setuju, 5 orang menjawab ragu-ragu, menjawab sangat tidak setuju tidak ada. Hal ini menunjukkan bahwa pelayanan informasi yang diberikan oleh Humas kurang memenuhi harapan dari masyarakat. Dari hasil wawancara dari responden diketahui bahwa Humas belum memberikan pelayanan informasi sesuai dengan harapan publik eksternal.

\section{Informasi}

Penulis meminta tanggapan tentang informasi yang diberikan oleh Humas. Informasi berupa program pemerintan ataupun kegiatan Humas. Dalam hal ini penulis mengamati tentang informasi yang diberikan oleh Humas sudah sesuai dengan harapan publik atau informasi tersebut sudah jelas dan mudah dipahami. Jawaban responden dapat dilihat pada tabel dibawah ini: 
Tabel 10. Tanggapan tentang informasi dari Humas

\begin{tabular}{|c|c|c|c|c|c|}
\hline No & Jawaban & $F$ & $\mathbf{X}$ & $f(x)$ & $\sum f(\mathrm{x}) / \mathrm{N}$ \\
\hline $\mathbf{A}$ & Sangat Setuju & 8 & 5 & 40 & \multirow{6}{*}{3,19} \\
\hline B & Setuju & 23 & 4 & 72 & \\
\hline C & Ragu-ragu & 6 & 3 & 18 & \\
\hline D & Tidak Setuju & 10 & 2 & 20 & \\
\hline $\mathbf{E}$ & Sangat Tidak Setuju & 0 & 1 & 0 & \\
\hline & Jumlah & 47 & & 150 & \\
\hline
\end{tabular}

Dari Tabel 10, tanggapan yang diberikan responden tentang informasi yang diberikan oleh Humas memeperoleh angka penafsiran sebesar 3,19 yang berada pada ketegori cukup. Dimana frekuensi jawaban dari 47 responden, 8 orang menjawab sangat setuju, 23 orang menjawab setuju, 6 menjawab ragu-ragu, 10 orang menjawab tidak setuju, menjawab sangat tidak setuju tidak ada. Hal ini menunjukan bahwa informasi yang diberikan oleh Humas belum memenuhi harapan dari masyarakat. Berdasarkan hasil wawancara dengan responden mereka jarang mendapatkan informasi yang jelas dari Humas karena terkadang informasi tersebut kurang dipahami oleh masyarakat.

\section{Hubungan Antara Variabel Penelitian}

Analisis Hubungan Efektivitas Kegiatan Humas dengan Citra Humas di mata publik eksternal, berdasarkan uji Rank Spearman dengan metode SPSS versi 16, diperoleh gambaran hubungan variabel efektivitas kegiatan Humas dengan variabel citra Humas di mata publik eksternal dapat dilihat pada tabel berikut:

Tabel 11. Hubungan antara efektivitas kegiatan humas dengan citra humas dimata public eksternal

\begin{tabular}{|c|c|c|c|}
\hline $\begin{array}{ll}\text { X= Efektivitas } & Y=\text { Citra Humas } \\
\text { Kegiatan Humas } & \end{array}$ & Sikap Humas & Pelayanan & Informasi \\
\hline $\begin{array}{l}\text { Dokumentasi } \\
\text { Klipping koran } \\
\text { Transkrip pidato }\end{array}$ & .122 & $.550^{* *}$ & .256 \\
\hline $\begin{array}{l}\text { Publikasi } \\
\text { Press Realeas } \\
\text { Bulletin } \\
\end{array}$ & $.345^{*}$ & $.457^{* *}$ & $.438^{* *}$ \\
\hline $\begin{array}{l}\text { Kegiatan Humas } \\
\text { Media Humas } \\
\text { Konferensi Pers } \\
\end{array}$ & $.369^{*}$ & $.492^{* *}$ & $.527^{* *}$ \\
\hline
\end{tabular}

*. Correlation is significant at the 0.05 level (2-tailed).

**. Correlation is significant at the 0.01 level (2-tailed). 
Berdasarkan data pada tabel 11, diketahui hubungan variabel efektivitas kegiatan Humas yang diuraikan dalam beberapa indikator pada taraf 0,05 dan 001 dengan variabel citra Humas. Berikut ini penjelasan pada setiap variabel penelitian:

\section{Hubungan Efektivitas Kegiatan Humas dengan Citra Humas di Mata Publik Eksternal}

1. Kegiatan Humas dokumentasi berhubungan nyata dengan satu indikator variabel citra Humas yaitu pelayanan informasi yang menyetujui bahwa pelayanan informasi yang diberikan oleh Humas adalah positif.
2. Kegiatan publikasi berhubungan nyata dengan dua indikator citra Humas yaitu pelayanan dan informasi. Dapat disimpulkan bahwa kegiatan publikasi berhubungan erat dengan citra Humas.

3. Kegiatan Humas berhubungan nyata dengan dua indikator citra Humas yaitu pelayanan dan informasi. Dapat disimpulkan bahwa kegiatan Humas berhubungan erat dengan citra Humas.

\section{Uji Hipotesis}

Uji hipotesis untuk mengetahui hubungan efektivitas kegiatan Humas dengan citra Humas di mata publik eksternal secara menyeluruh berdasarkan uji Rank Spearman dapat dilihat pada tabel berikut.

Tabel 12. Hasil uji hipotesis

\section{Correlations}

\begin{tabular}{|lll|r|r|}
\hline & & jumlah $\mathrm{x}$ & Jumlah Y \\
\hline Spearman's rho & Jumlah $\mathrm{x}$ & Correlation Coefficient & 1.000 & $.667^{* *}$ \\
& Sig. (2-tailed) &. & .000 \\
& $\mathrm{~N}$ & 47 & 47 \\
\cline { 2 - 5 } & Correlation Coefficient & $.667^{* *}$ & 1.000 \\
& Sig. (2-tailed) & .000 & \\
$\mathrm{~N}$ & 47 & 47 \\
\hline
\end{tabular}

**. Correlation is significant at the 0.01 level (2-tailed).

Bogor dengan citra Humas di mata publik eksternal memiliki hubungan yang positif dengan kategori tingkat hubungan keeratan yang signifikan.

Setelah melakukan analisa korelasi terhadap dua variabel penelitian kemudian dilakukan pembuktian hipotesis. Hasil analisa koreksi menyatakan bahwa pengaruh yang berbentuk antara variabel efektivitas kegiatan Humas pemerintah kota Bogor dengan citra Humas di mata publik eksternal berada pada kategori kuat dengan angka koefisien korelasi sekitar 0,667 .

Berdasarkan pada tabel 17 diatas, analisa korelasi antara efektivitas kegiatan Humas dengan citra Humas pemerintah kota Bogor dengan citra Humas di mata publik eksternal didapat koefisien korelasi sebesar 0,667 sehingga dapat disimpulkan bahwa korelasi efektivitas kegiatan Humas pemerintah kota
Angka koefisien positif menunjukkan hubungan positif yaitu semakin efektifnya kegiatan Humas maka semakin tinggi citra Humas yang diharapkan oleh Humas. Untuk itu menentukan diterima atau ditolaknya hipotesa maka pengujian signifikan koefisien korelasi dengan rumus t-tes.

Dari hasil perhitungan diperoleh nilai thitung hasil penelitian sebesar 5,34. Kemudian nilai $t_{\text {hitung }}$ dibandingkan dengan $t_{\text {tabel }}$ distribusi $t$ dengan taraf signifikan tak terhinggan $\mathrm{dk} 2,01$ $\left(t_{\text {tabel }}\right)$ jadi $\mathrm{H}_{\mathrm{a}}$ diterima dan $\mathrm{H}_{0}$ ditolak. Jadi, dapat disimpulkan bahwa terdapat hubungan yang signifikan antara efektivitas kegiatan Humas pemerintah Kota Bogor dengan citra 
Humas dengan kekuatan hubungan yang kuat juga sangat signifikan, maka hipotesis dalam penelitian ini diterima.

\section{KESIMPULAN DAN SARAN}

\section{Kesimpulan}

Kegiatan Humas pemerintah Kota bogor yang dilaksanakan selama ini sudah efektif, khususnya kegiatan Humas dokumetasi. Hal ini dapat dilihat dari publik ekternal yang sudah mengetahui bentuk dari kegiatan Humas. Kegiatan Humas tersebut memberikan gambaran bahwa Humas dengan publik eksternal memiliki hubungan yang cukup baik.

Kegiatan Humas berhasil membentuk citra yang positif pada publik eksternal yang selalu membutuhkan pelayanan informasi dengan Humas. Pelayanan informasi yang baik dari Humas juga dinilai sebagai salah satu bentuk kepedulian dari Humas. Penilaian positif dari publik eksternal menunjukkan bahwa Humas selalu berusaha untuk memberikan informasi dan pelayanan dengan baik.

Efektivitas kegiatan Humas berhasil menumbuhkan citra positif pada publik eksternal. Hal ini ditunjukan oleh hasil penelitian yang menyatakan bahwa terdapat hubungan yang kuat dan signifikan antara efektivitas kegiatan Humas Pemerintah Kota Bogor dengan citra Humas di mata publik eksternal. Dengan demikian hipotesis penelitian terbukti.

\section{Saran}

Untuk menjalin hubungan yang baik antara Humas dengan publik eksternal sebaiknya Humas meningkatkan komunikasi dua arah, misalnya Humas mengadakan penyuluhan, seminar untuk mengukur tingkat respon publik. Sehingga publik ekternal merasa turut dalam kebijakan-kebijakan yang diambil oleh Pemerintah Kota Bogor.

Untuk meningkatkan citra Humas Pemerintah Kota Bogor dengan cara meningkatkan pelayanan informasi dengan publik. Humas haruslah menerapkan suatu kinerja yang maksimal dengan mengoptimalkan sumber daya yang sudah tersedia dan lebih banyak mengadakan kegiatan yang melibatkan masyarakat agar Pemerintah dan Humas mendapat citra yang positif.

\section{DAFTAR PUSTAKA}

Bungin, Burhan. 2010. Metodologi Penelitian Kuantitatif.Jakarta : Kencana

]emerson.1996. Manajeman Efektivitas, Bandung : Rosdakarya

Jefkins, Frank.1996. Public Relations. Penerjemah: Haris Munandar. Jakarta. Erlangga

Hasan, Erliana. 2005. Komunikasi Pemerintahan. Bandung : Rafika Aditama

Moore, Frazier. 2004. Humas Membangun Citra Dengan Reputasi, Bandung : Rosdakarya

Seidel, J.C. 2001. Dasar-dasar Public Relation. Bandung : Rosdakarya

Siregar, Bakri.1993. Metode Riset Sosial.Jakarta. CV Kurnia

Tim Fokusmedia, 2007. Organisasi Perangkat Daerah. Bandung : Fokusmedia

Widjaja, H.A.W. 2002. Komunikasi dan Hubungan Masyarakat. Jakarta : Bumi Aksara. 
